Vol 1. No 1. Juli 2021 e-ISSN : 2798-5733 P-ISSN : 2798-5741

\title{
PENINGKATAN KINERJA GURU DALAM MENYUSUN STRATEGI PEMBELAJARAN MELALUI KEGIATAN WORKSHOP DI SMAN 7 MUARO JAMBI TAHUN PELAJARAN 2018/2019
}

\author{
AHMAD YANI \\ Kepala SMA Negeri 7 Muaro Jambi Provinsi Jambi \\ Email : A.yaniJambi123@gmail.com
}

\begin{abstract}
ABSTRAK
Penelitian ini bertujuan untuk: (1) untuk mengetahui kegiatan workshop yang dapat meningkatkan kinerja guru dalam menyusun strategi pembelajaran; (2) untuk mengetahui peran kegiatan workshop dalam meningkatkan kinerja guru dalam mengajar di SMA Negeri 7 Muaro Jambi; (3) untuk mengetahui kendala apa saja yang dihadapi dalam pelaksanaan kegiatan workshop untuk meningkatkan kinerja guru dalam menerapkan strategi pembelajaran di SMA Negeri 7 Muaro Jambi; (4) untuk mengetahui usaha yang telah dilakukan oleh kepala Sekolah di SMA Negeri 7 Muaro Jambi dalam meningkatkan kinerja guru untuk menerapkan strategi pembelajaran. Penelitian ini merupakan penelitian tindakan (action research) yang bertujuan untuk meningkatkan kinerja guru dalam menyusun strategi pembelajaran melalui workshop di SMA Negeri 7 Muaro Jambi. Tindakan yang akan dilakukan adalah workshop penyusunan strategi pembelajaran. Jenis penelitian tindakan yang dipilih adalah jenis emansipatori. subjek penelitian ini adalah guru di SMA Negeri 7 Muaro Jambi yang berjumlah 26 orang, yang terdiri atas: 8 orang guru laki-laki dan 18 orang guru perempuan. Sedangkan yang menjadi objek penelitian adalah kinerja guru dalam menyusun strategi pembelajaran.
\end{abstract}

Kata Kunci: kinerja guru, strategi pembelajaran, workshop

\section{PENDAHULUAN}

Pendidikan Indonesia dewasa ini mengalami kemajuan yang cukup signifikan. Pembaruan yang terjadi tidak dapat terlepas dari upaya pemerintah dalam memajukan system pendidikan nasional yang bermutu dan berdaya saing baik secara nasional dan global. Pembaharuan tersebut tertuang dalam Undang-undang No. 20 tahun 2003 yang mana Sistem Pendidikan Nasional semakin terarah setelahnya munculnya PP no. 19 tahun 2005 tentang Standar Nasional Pendidikan. Adapun standar tersebut terdiri dari 8 standar yang meliputi: 1) Standar isi, 2) standar proses, 3) standar kompetensi lulusan, 4) standar pendidik dan tenaga kependidikan, 5) standar sarana dan prasarana, 6) standar pengelolaan, 7) standar pembiayaan, dan 8) standar penilaian pendidikan.

Salah satu standar nasional pendidikan yang sangat penting dalam pembaharuan pendidikan adalah standar pendidik dan tenaga kependidikan yang menjadi salah satu masalah pendidikan yang sedang dihadapi oleh negara Indonesia adalah masih rendahnya kualitas pendidikan. Hal tersebut disebabkan karena rendahnya kualitas tenaga pendidikan yang ada khususnya guru. Menurut Mujtahid (2011: 33) Guru adalah elemen kunci dalam system pendidikan, khususnya di sekolah. Semua komponen yang lain, mulai dari lulusan, kurikulum, sarana dan prasarana, pembiayaan, dan sebagainya tidak akan berarti apa-apa apabila interaksi guru dengan peserta didik tidaklah berkualitas (Iskandar, 2013: 10). Guru benar-benar dituntut untuk memliliki kinerja yang mampu memberikan dan merealisasikan harapan dan keinginan semua pihak terutama masyarakat umum yang telah mempercayai sekolah dan guru dalam membina anak didik. Dalam meraih mutu pendidikan yang baik sangat dipengaruhi oleh kinerja guru dalam melaksanakan tugasnya sehingga mampu mencapai keberhasilan pendidikan. Seorang guru menghasilkan kinerja yang tinggi sangat bergantung pula pada pengelolaan proses pembelajaran.Dalam meningkatakan kualitas pendidikan dipengaruhi oleh penyempurnaan seluruh komponen pendidikan, Namun disini guru merupakan komponen paling menentukan, karena ditangan gurulah komponen-komponen lain menjadi sesuatu yang 
berarti bagi peserta didik. Guru sebagai tenaga pendidikan secara subtantif memegang peranan tidak hanya melakukan pengajran atau transfer ilmu pengetahuan (kognitif), tetapi dituntut untuk mampu memberikan bimbingan dan pelatihan (Rahmatullah, 2017: 119).

Salah satu upaya yang dapat ditempuh kepala sekolah dalam meningkatkan kinerja guru adalah melalui adanya strategi dan model pembelajaran yang harus diterapkan oleh guru dalam proses pembelajaran. Penerapan strategi dan model pembelajaran yang tepat akan berdampak positif bagi siswa (Arman, 2019: 216). Pebelajaran adalah prosess, cara menjadikan orang untuk belajar Strategi pembelajaran adalah komponen umum dari suatu rangkaian materi dan prosedur pembelajaran yang akan digunakan secara bersama-sama oleh guru dan siswa selama proses pembelajaran berlangsung. Dengan demikian, kinerja menyusun strategi pembelajaran adalah kapasitas seorang guru dalam membuat perencanaan pembelajaran yang membuat cara-cara melaksanakan pembelajaran sehingga pembelajaran mencapai tujuan sesuai dengan yang telah ditetapkan (Solihatin, 2012: 3).Ketika menjalankan tugasnya guru tidak bergantung pada tugas itu sendiri, tetapi guru bergantung pada bagaimana cara pandang guru atas tugas tersebut dan bergantung pada wawasan yang dimilikinya. (Darmadi, 2016: 161). Hal tersebut juga mengharuskan guru untuk memilih strategi pembelajaran dengan sebaik-baiknya supaya tercapai tujuan pendidikan dengan baik. Masingmasing guru memilih strategi yang berbeda-beda dalam proses pembelajaran disebabkan oleh perbedaan pengalaman, pengetahuan, kemampuan menyajikan pelajaran, gaya mengajar, pandangan hidup, dan wawasan masing-masing (Suryana, 2013). Pemilihan strategi pembelajaran bukan hanya dilihat dari sisi guru saja, namun juga harus dilihat dari semua unsur yakni kebutuhan siswa, jenis materi pelajaran, dan sarana pendukung belajar (Heri, 2014: 20).

Namun kenyataan yang ada dari hasil supervisi menunjukkan bahwa $60 \%$ guru di kelas masih mendominasi menggunakan strategi dan model pembelajaran yang konvensional. Strategi adalah cara untuk menempatkan sesuatu sehingga menjadi suatu tujuan (Supardi, 2014: 45).Kinerja guru akan bermakna bila dibarengi dengan niat yang bersih dan ikhlas, serta selalu menyadari akan kekurangan yang ada pada dirinya dan berupaya untuk dapat menghilangkan kekurangan tersebut sebagai upaya untuk meningkatkan kearah yang lebih baik. Kinerja yang dilakukan hari ini harus lebih baik dari kinerja hari kemarin, dan tentunya kinerja masa depan harus lebih baik dari kinerja hari ini. Dijelaskan bahwa tinggi atau rendahnya guru akan berpengaruh terhadap terlaksananya tugas yang diemban, dimana hal tersebut akan berpengaruh terhadap pencapaian kinerja pada proses pembelajaran serta pencapaian tujuan pendidikan (Karweti, 2010: 77). Melihat kondisi tersebut, ada beberapa upaya yang bisa dilakukan untuk meningkatkan kinerja mengajar guru di sekolah. Seperti yang diungkapkan (Risnawan, 2007:40) mengungkapkan bahwa Alternatif program pengembangan profesionalisme guru antara lain Program Peningkatan Kualifikasi Pendidikan Guru, Program Penyeteraan dan Sertifikasi, Program Pelatihan Terintegrasi Berbasis Kompetensi, Program Supervisi Pendidikan, Program Pemberdayaan MGMP, Simposium Guru, Program Pelatihan Tradisional, Membaca dan Menulis Jurnal atau Karya Ilmiah, Berpartisipasi dalam Pertemuan Ilmiah, Melakukan Penelitian, Magang, Mengikuti Berita Aktual dari Media Pemberitaan, Berpartisipasi dan Aktif Dalam Organisasi Profesi serta Menggalang Kerja sama dengan Teman Seprofesi.

Guru memiliki peranan strategis dalam mewujudkan tujuan pendidikan nasional. Hal itu dapat dipahami karena gurulah yang langsung berhubungan dengan peserta didik, perkembangan baru terhadap pandangan belajar-mengajar membawa konsekuensi kepada guru untuk terus meningkatkan peranan dan kompetensinya. Pada intinya guru merupakan sentral dari upaya peningkatan mutu pendidikan, oleh sebab itu setiap upaya untuk membenahi pendidikan akan dan harus melibatkan guru sehingga mampu mencetak guru yang memiliki kinerja yang baik (Fahrurrozi et al, 2021). Profesi guru masih banyak dibicarakan dan dipertanyakan orang baik di kalangan pakar pendidikan maupun di luar pakar pendidikan. 
Masyarakat atau orang tua siswa kadang-kadang mencemoohkan dan menuding guru tidak kompeten, tidak berkualitas dan sebagainya.

Dalam meningkatkan kompetensi guru salah satu strategi dalam meningkatkan penguasan guru adalah pelatihan dan workshop. Hasil temuan yang dilakukan oleh (Harahap, 2014) temuan penelitian ini menemukan bahwa penerapan supervisi akademik teknik Workshop dapat meningkatkan pembelajaran aktif. Dipertegas dalam temuan (Gunawan et al., 2017) Variasi guru dalam menerapkan strategi pembelajaran menjadi hal yang penting dilakukan dalam kegiatan pembelajaran. Kebaharuan pada penelitian ini lebih kepada mengetahui kemampuan guru kelas dalam Menyusun strategi pembelajaran dan kompetensi dalam penguasaaan materi pembelajaran, sehingga peneliti tertarik untuk mengetahui kemampuan guru SMAN 7 Muaro Jambi dalam penyusunan strategi pembelajaran serta bagaimana penguasaan materi pembelajaran yang diberikan oleh guru kelas. Begitu juga dengan hasil penelitian yang relevan yang dilakukan oleh Sudiati, 2018 disebutkan bahwa melalui workshop dapat meningkatkan kinerja guru dalam menetapkan kriteria ketuntasan minimal di SMK Ma'arif NU Sunan Giri Driyorejo.

\section{METODE PENELITIAN}

Penelitian ini merupakan penelitiantindakan (action research) yang bertujuan untuk meningkatkan kinerja guru menyusun strategi pembelajaran melalui workshop di SMA Negeri 7 Muaro Jambi. Tindakan yang akan dilakukan adalah workshop penyusunan strategi pembelajaran.Yang menjadi subjek penelitian ini guru-guru di SMA Negeri 7 Muaro Jambi yang berjumlah 26 orang, yang terdiri atas: 8 orang guru laki-laki dan 18 orang guru perempuan. Sedangkan yang menjadi objek penelitian adalah kinerja guru dalam menyusun strategi pembelajaran. Penelitian dilakukan pada seluruh guru SMA Negeri 7 Muaro Jambi semester Ganjil Tahun Pelajaran 2018/2019. Pemilihan lokasi penelitian karena sekolah tersebut merupakan sekolah tempat peneliti menjadi kepala sekolah. Disamping itu pula, dari hasil supervisi ditemukan kelemahan guru dalam menyusun strategi pembelajaran.

\section{HASIL DAN PEMBAHASAN}

Gambaran hasil yang didapat berdasarkan rekaman fakta/observasi di lapangan, para guru di SMA Negeri 7 Muaro Jambi pada awalnya pemahaman terhadap strategi pembelajaran sangat kurang, hal ini dikarenakan persepsi guru menganggap bahwa strategi pembelajaran tidak terlalu penting, penyusuanan strategi pembelajaran hanya merupakan persyaratan administrasi sehingga strategi pembelajaran yang dibuat tidak sesuai dengan karakatristik mata pelajaran dan siswa. Demikian pula tampak jelas, kinerja guru dalam menyusun strategi pembelajaran hanya didasari oleh contoh-contoh yang ada tanpa menganalisis secara kritis berdasarkan standar yang ada sehingga kualitas strategi pembelajaran jauh dari apa yang diharapkan. Hampir semua guru ditemukan kurang paham semua aspek yang ada dalam menyusun strategi pembelajaran. Kesalahan umum yang tampak adalah: (1) guru belum mampu menyusun tujuan pembelajaran, (2) guru belum mampu menguraikan materi ajar dengan baik, (3) guru belum mampu membuat langkah-langkah pembelajaran sesuai metode pembelajaran yang dituliskan, (4) guru belum mampu membuat penilaian sesuai dengan metode yang digunakan, dan (5) guru belum mampu memanejemn waktu baik dalam kegiatan awal, inti dan penutup. Dengan kondisi awal seperti ini perlu adanya tindakan nyata yang diharapkan mampu meningkatkan kinerja guru dalam menyusun strategi pembelajaran, yakni berupa workshop.

\section{Siklus I}

Perencanaan terdiri atas: (1) melaporkan kegiatan penelitian kepada pengawas sekolah binaan atas nama, Kepala Dinas beserta mohon ijin penelitian, (2) berkoordinasi dengan wakil kepala sekolah untuk menyampaikan ijin penelitian dari Kepala Dinas Pendidikan, dengan minta masukan tentang masalah yang ada sekaligus membicarakan tentang masalah teknis, 
waktu pelaksanaan penelitian dan hal-hal yang terkait dengan penelitian dan atau workshop yang dilaksanakan, (3) bersama Pengawas Sekolah memberikan pengarahan tentang workshop strategi pembelajaran, (4) mengelompokkan guru berdasarkan mata pelajaran, (5) menelaah konsep strategi pembelajaran, mengkonsep strategi pembelajaran yang mendekati kondisi mata pelajaran, (6) mendiskusikan konsep strategi pembelajaran dan presentasi kelompok, (7) presentasi kelas, dan (8) menghasilkan strategi pembelajaran final.

Selanjutnya Pada tahap tindakan dilakukan beberapa langkah, yakni: (1)absensi peserta, (2) pengarahan kepala sekolah, (3) penjelasan umum kepada seluruh peserta, (3) peserta dikelompokan sesuai mata pelajaran, (4) guru mengkaji: standard kompetensi, kompetensi dasar (KD) sesuai model silabus mata pelajaran masing-masing, materi pembelajaran, indikator, penilaian,(5) guru menyusun strategi pembelajaran sesuai format yang telah disepakati yang berisi tentang aspek, materi dan kegiatan, dan (6) presentasi visual strategi pembelajaran.

Pada tahap hasil observasi dilakukan pengamatan terhadap pelaksanaan tindakan yaitu menitikberatkan pada kompetensi guru dalam menyusun strategi pembelajaran sebagai akibat diterapkan workshop. Tujuan dilaksanakan pengamatan adalah untuk mengetahui kegiatan yang mana patut dipertahankan, diperbaiki atau dihilangkan sehingga kegiatan pembinaan melalui workshop benar-benar berjalan sesuai dengan tujuan yang ada dan mampu meningkatkan kinerja peserta dalam menyusun strategi pembelajaran. Dari hasil evaluasi terhadap penyusunan strategi pembelajaran yang dibuat oleh 26 orang guru setelah diadakan workshop pada tahap awal (siklus I) diperoleh kinerja guru menyusun strategi pembelajaran seperti tampak pada Tabel 1. berikut:

Tabel 1. Rangkuman Hasil Penilaian Komptensi Guru dalam Menyusun Strategi Pembelajaran pada Siklus I

\begin{tabular}{|c|c|c|c|c|c|c|c|c|c|}
\hline \multirow{3}{*}{ No } & \multirow{3}{*}{ AspekyangDinilai } & \multicolumn{8}{|c|}{ Skor } \\
\hline & & \multicolumn{2}{|c|}{1} & \multicolumn{2}{|c|}{2} & \multicolumn{2}{|c|}{3} & \multicolumn{2}{|c|}{4} \\
\hline & & Jml & $\%$ & $\mathrm{Jml}$ & $\%$ & $\mathrm{Jml}$ & $\%$ & Jml & $\%$ \\
\hline 1 & Format & 3 & 11.54 & 3 & 11.54 & 10 & 38.46 & 10 & 38.46 \\
\hline 2 & $\begin{array}{l}\text { Relevansi antara waktu } \\
\text { dengan bahan } \\
\text { ajar }\end{array}$ & 2 & 7.69 & 4 & 15.38 & 8 & 30.76 & 12 & 46.15 \\
\hline 3 & $\begin{array}{l}\text { Pembukaan (apersepsi,pre- } \\
\text { tes) }\end{array}$ & 1 & 3.85 & 4 & 15.38 & 10 & 38.46 & 11 & 42.31 \\
\hline 4 & $\begin{array}{l}\text { Inti (kesesuaian antara } \\
\text { pembelajaran sesuai } \\
\text { dengan bahan ajar, kualitas } \\
\text { urutan penyajian, kualitas } \\
\text { Penugasan siswa, dan } \\
\text { waktu }\end{array}$ & 3 & 11.54 & 5 & 19.23 & 8 & 30.77 & 10 & 38.46 \\
\hline
\end{tabular}

$\begin{array}{llllllllll}5 & \text { Penutup (simpulan, postes) } & 2 & 7.69 & 4 & 15.38 & 8 & 30.77 & 12 & 46.15\end{array}$

Dari Tabel 1. di atas, pada aspek format; 3 orang atau 11,54\% guru dalam kategori tidak baik, 3 orang atau 11,54\% tergolong cukup, 10 orang atau 38,46\% tergolong baik dan 10 orang atau $38,46 \%$ tergolong sangat baik. Bila dijumlahkan antara yang berkategori baik dan sangat baik mencapai 20 orang atau 76,92\%. Pada aspek relevansi antara waktu dengan bahan ajar, tampak bahwa 2 orang atau 7,69\% tergolong tidak baik, 4 orang atau 15,38\% tergolong cukup, 8 orang atau 30,76\% tergolong baik dan 12 orang atau 46,15\% tergolong sangat baik. Bila dijumlahkan antara yang baik dan sangat baik mencapai 20 orang atau 76,91\%. Pada aspek pembukaan; 1 orang atau 3,85\% guru dalam kategori tidak baik, 4 orang 
atau 15,38\% tergolong cukup, 10 orang atau 38,46\% tergolong baik dan 11 orang atau $42,31 \%$ tergolong sangat baik. Bila dijumlahkan antara yang berkategori baik dan sangat baik mencapai 21 orang atau 80,77\%. Pada aspek inti pembelajaran; 3 orang atau 11,54\% guru dalam kategori tidak baik, 5 orang atau $19,23 \%$ tergolong cukup, 8 orang atau $30,77 \%$ tergolong baik dan 10 orang atau 38,46\% tergolong sangat baik. Bila dijumlahkan antara yang berkategori baik dan sangat baik mencapai 18 orang atau 69,23\%. Pada aspek penutup pembelajaran; 2 orang atau 7,69\% guru dalam kategori tidak baik, 4 orang atau 15,38\% tergolong cukup, 8 orang atau 30,77\% tergolong baik dan 12 orang atau 46,15\% tergolong sangat baik. Bila dijumlahkan antara yang berkategori baik dan sangat baik mencapai 20 orang atau $76,92 \%$.

Dari masalah tersebut, diputuskan untuk memperbaiki beberapa langkah dalam siklus I, yakni memfokuskan pada penjelasan tentang format dan aspek penilaian dalam kaitannya dengan menyusun strategi pembelajaran. Langkah- langkah ini dijalankan pada siklus II dengan tetap mempertahankan kegiatan yang lain yang sudah dianggap baik. Untuk meningkatkan kesiapan guru, fasilitator memberikan kesadaran bahwa petapa penting perencanaan pembelajaran yang dibuat guru sebelum melaksanakan pembelajaran. Mengenai altrnatif untuk menambah laptop diputuskan untuk memanfaatkan komputer (PC) yang ada di sekolah sehingga semua guru mendapatkan satu persatu.

\section{Siklus II}

Pada siklus II, langkah-langkah yang diambil sesuai dengan refleksi hasil siklus I mengikuti langlah-langkah seperti siklus I dengan memfokuskan pada penjelasan aspek-aspek yang belum dipahami guru dalam menyusun strategi pembelajaran lebih menitikberatkan pada aspek pembimbingan secara individu. Dari hasil evaluasi terhadap penyusunan strategi pembelajaran yang dibuat oleh 26 orang guru setelah diadakan workshop pada siklus II diperoleh kinerja guru menyusun strategi pembelajaran seperti tampak pada tabel 2 . berikut:

Tabel 2. Rangkuman Hasil Penilaian Komptensi Guru dalam Menyusun Strategi pembelajaran pada Siklus II

\begin{tabular}{|c|c|c|c|c|c|c|c|c|c|}
\hline \multirow{3}{*}{ No } & \multirow{3}{*}{ AspekyangDinilai } & \multicolumn{8}{|c|}{ Skor } \\
\hline & & \multicolumn{2}{|c|}{1} & \multicolumn{2}{|c|}{2} & \multicolumn{2}{|c|}{3} & \multicolumn{2}{|c|}{4} \\
\hline & & Jml & $\%$ & $\mathrm{Jml}$ & $\%$ & $\mathrm{Jml}$ & $\%$ & $\mathrm{Jml}$ & $\%$ \\
\hline 1 & Format & 0 & 0.00 & 2 & 7.69 & 10 & 38.46 & 14 & 53.85 \\
\hline 2 & $\begin{array}{l}\text { Relevansi } \\
\text { antarawaktudenganbahan } \\
\text { ajar }\end{array}$ & 0 & 0.00 & 2 & 7.69 & 11 & 42.31 & 13 & 50.00 \\
\hline 3 & $\begin{array}{l}\text { Pembukaan(apersepsi,pre- } \\
\text { tes) }\end{array}$ & 0 & 0.00 & 4 & 15.38 & 11 & 42.31 & 11 & 42.31 \\
\hline 4 & $\begin{array}{l}\text { Inti (kesesuaian } \\
\text { antarapembelajaran } \\
\text { sesuaidengan bahan } \\
\text { ajar,kualitas } \\
\text { urutanpenyajian, } \\
\text { kualitaspenugasansiswa,da } \\
\text { n } \\
\text { waktu }\end{array}$ & 1 & 3.85 & 2 & 7.69 & 10 & 38.46 & 13 & 50.00 \\
\hline 5 & Penutup (simpulan,postes) & 1 & 3.85 & 1 & 3.85 & 10 & 38.46 & 14 & 53.85 \\
\hline
\end{tabular}

Dari Tabel 2. diatas, pada aspek format; tidak ada orang atau $0,00 \%$ guru dalam kategori tidak baik, 2 orang atau 7,69\% tergolong cukup, 10 orang atau 38,46\% tergolong 
baik dan 14 orang atau 53,85\% tergolong sangat baik. Bila dijumlahkan antara yang berkategori baik dan sangat baik mencapai 24 orang atau 92,31\%. Pada aspek relevansi antara waktu dengan bahan ajar, tampak bahwa 0 orang atau 0,00\% tergolong tidak baik, 2 orang atau $7,69 \%$ tergolong cukup, 11 orang atau $42,31 \%$ tergolong baik dan 13 orang atau 50,00\% tergolong sangat baik. Bila dijumlahkan antara yang baik dan sangat baik mencapai 24 orang atau $92,31 \%$. Pada aspek pembukaan; 0 orang atau $0,00 \%$ guru dalam kategori tidak baik, 4 orang atau $15,38 \%$ tergolong cukup, 11 orang atau 42,31\% tergolong baik dan 11 orang atau $42,31 \%$ tergolong sangat baik. Bila dijumlahkan antara yang berkategori baik dan sangat baik mencapai 22 orang atau 84,62\%. Pada aspek inti pembelajaran; 1 orang atau 3,85\% guru dalam kategori tidak baik, 2 orang atau 7,69\% tergolong cukup, 10 orang atau 38,46\% tergolong baik dan 13 orang atau 50,00\% tergolong sangat baik. Bila dijumlahkan antara yang berkategori baik dan sangat baik mencapai 23 orang atau $88,46 \%$. Pada aspek penutup pembelajaran; 1 orang atau 3,85\% guru dalam kategori tidak baik, 1 orang atau 3,85\% tergolong cukup, 10 orang atau 38,46\% tergolong baik dan 14 orang atau 53,85\% tergolong sangat baik. Bila dijumlahkan antara yang berkategori baik dan sangat baik mencapai 24 orang atau $92,31 \%$.

Berdasarkan dekripsi pada tabel 1 dan 2 tampaknya kinerja guru menyusun strategi pembelajaran para guru sudah memenuhi indikator kinerja yang telah ditetapkan pada semua aspek, baik menyangkut kesiapan maupun kinerja menyusun strategi pembelajaran. Dengan hasil seperti itu, berarti tindakan yang diberikan efektif dalam meningkatkan kinerja guru dalam menyusun strategi pembelajaran.

\section{Respon Guru terhadap Penyusunan Strategi Pembelajaran Melalui Workshop}

Penilaian ini penting dilakukan untuk memperoleh gambaran tentang respon guru terhadap kegiatan workshop yang telah diterapkan dalam menyusun strategi pembelajaran. Bila guru merespon positif terhadap kegiatan tersebut, maka kegiatan tersebut perlu dilanjutkan dalam kegiatan-kegiatan yang lain.

Tabel 3. Skor Respon Nilai Penyusunan Strategi Pembelajaran Melalui Workshop

\begin{tabular}{lcccc}
\hline No. & Kode & Skor Pra Tindakan & Skor SiklusI & Skor SiklusII \\
& Nama Guru & & 70 & 85 \\
\hline 1 & SA & 57 & 72 & 72 \\
\hline 2 & BA & 58 & 80 & 85 \\
\hline 4 & HY & 60 & 70 & 80 \\
\hline 5 & MW & 61 & 70 & 85 \\
\hline 6 & SS & 62 & 72 & 72 \\
\hline 7 & KH & 58 & 85 & 85 \\
\hline 8 & KL & 65 & 72 & 80 \\
\hline 9 & JL & 58 & 80 & 85 \\
\hline 10 & MD & 61 & 85 & 85 \\
\hline 11 & JL & 63 & 70 & 85 \\
\hline 12 & HS & 60 & 72 & 85 \\
\hline 13 & KD & 50 & 80 & 72 \\
\hline 14 & MM & 52 & 70 & 80 \\
\hline 15 & YA & 53 & 72 & 80 \\
\hline 16 & LW & 62 & 80 & 72 \\
\hline 17 & AF & 53 & & 85 \\
\hline 18 & FJ & 58 & 70 & 8 \\
\hline
\end{tabular}


Vol 1. No 1. Juli 2021 e-ISSN : 2798-5733 P-ISSN : 2798-5741

\begin{tabular}{llccc}
\hline 19 & ME & 61 & 70 & 80 \\
\hline 20 & PY & 60 & 72 & 85 \\
\hline 21 & TA & 62 & 85 & 82 \\
\hline 22 & RV & 58 & 72 & 85 \\
\hline 23 & CD & 50 & 80 & 86 \\
\hline 24 & HL & 52 & 85 & 80 \\
\hline 25 & WK & 53 & 70 & 85 \\
\hline 26 & IM & 62 & 72 & 85 \\
\hline & & $\mathbf{1 5 1 4}$ & $\mathbf{1 9 5 6}$ & $\mathbf{2 1 1 6}$ \\
\hline & $\mathbf{5 8 . 2 3}$ & $\mathbf{7 5 . 2 3}$ & $\mathbf{8 1 . 3 8}$ \\
\hline
\end{tabular}

Bila dicocokkan dengan klasifikasi di atas, respon guru tergolong sangat positif dimana dapat dilihar berdasarkan tabel 3 dimana skor pra-tindakan adalah $\mathbf{5 9 , 2 3}$ dan pada siklus 1 mengalami peningkatan yang signifikan dengan rata-rata nilai $\mathbf{7 5 , 2 3}$ begitu juga dengan pelaksanaaan siklus II mengalami peningkatan yang signifikan dengan nilai rata-rata skor 81,38. Dengan demikian kegiatan workshop menyusun strategi pmebelajaran mendapat respon yang sangat positif dari guru SMA Negeri 7 Muaro Jambi. Oleh karena itu, penerapannya perlu dilanjutkan dalam kegiatan-kegiatan yang lain.

Dari paparan di atas, menunjukkan bahwa peningkatan kompetensi guru melalui kegiatan workshop yang lebih menekankan pada metode kolaboratif konsultatif akan memberikan kesempatan sharing antara satu guru dengan guru lain. Dengan demikian, pemahaman terhadap strategi pembelajaran dapat ditingkatkan baik dalam teoretisnya maupun implementasinya.

\section{KESIMPULAN}

Berdasarkan analisis dan pembahasan seperti yang telah dipaparkan pada bagian sebelumnya, maka dapat disimpulkan bahwa: (1) Terjadi peningkatan kesiapan peserta dalam kegiatan workshop di SMAN 7 Muaro Jambi . Di samping itu juga, terjadi peningkatan kinerja guru dalam menyusun strategi pembelajaran melalui pembinaan berupa workshop di SMA Negeri 7 Muaro Jambi dimana skor pra-tindakan adalah 59,23 dan pada siklus 1 mengalami peningkatan yang signifikan dengan rata-rata nilai $\mathbf{7 5 , 2 3}$ begitu juga dengan pelaksanaaan siklus II mengalami peningkatan yang signifikan dengan nilai rata-rata skor 81,38. Dengan demikian siklus I ke siklus II dan mencapai target minimal yang telah ditetapkan yakni $80,0 \%$, artinya $80,0 \%$ guru telah efektif dalam menyusun strategi pembelajaran pada masing-masing aspek. Dengan demikian dapat disimpulkan bahwa melalui workshop dapat meningkatkan kinerja guru dalam menyusun strategi pembelajaran di SMA Negeri 7 Muaro Jambi; dan (3) Seluruh dewan guru SMA Negeri 7 Muaro Jambi memberikan respon sangat positif terhadap kegiatan penyusuan strategi pembelajara melalui workshop. Dengan demikian kegiatan workshop memberikan dampak positif terhadap kinerja guru dalam menyusun strategi pembelajaran.

\section{DAFTAR PUSTAKA}

Arman, A. (2019). Peningkatan Kemampuan Kinerja Guru dalam Menyusun Strategi Pembelajaran melalui Kegiatan Workshop di MIN 6 Bener Meriah. Jurnal Serambi Akademica, 7(3), 216-225.

Darmadi, H. (2016). Tugas, peran, kompetensi, dan tanggung jawab menjadi guruprofesional. Edukasi: Jurnal Pendidikan, 13(2), 161-174.

Fahrurrozi, M., Mohzana, M., \& Murcahyanto, H. (2021). Strategi Pembelajaran dan Kemampuan Guru Kelas. JOEAI: Journal of Education and Instruction, 4(1), 197205. 
Gunawan, I., Ulfatin, N., Sultoni, S., Sunandar, A., Kusumaningrum, D. E., \& Triwiyanto, T. (2017). Pendampingan Penerapan Strategi Pembelajaran Inovatif dalam Implementasi Kurikulum 2013. Abdimas Pedagogi: Jurnal Ilmiah Pengabdian Kepada Masyarakat, 1(1).

Harahap, D. P. (2014). Supervisi akademikteknik workshop meningkatkan kemampuan guru melaksanakan pembelajaran aktif. Jurnal Manajemen Pendidikan Indonesia, 6(02), $67-76$.

Heri, S. (2014). Seputar Pembelajaran Sejarah; Isu, Gagasan dan Strategi Pembelajaran. Yogyakarta: Aswaja Pressindo.

Iskandar, U. (2013). Kepemimpinan kepala sekolah dalam peningkatan kinerja guru. Jurnal visi ilmu pendidikan, 10(1).

Karweti, E. (2010). Pengaruh kemampuan manajerial kepala sekolah dan faktor yang mempengaruhi motivasi kerja terhadap kinerja guru SLB di Kabupaten Subang. Jurnal penelitian pendidikan, 11(2), 77-89.

Mujtahid. (2011). Pengembangan Profesi Guru. Malang: UIN Maliki Press.

Rahmatullah, M. (2017). Kemampuan mengajar guru dalam meningkatkan kinerja guru dan hasil belajar siswa. Tanzhim, 1(02), 119-126.

Solihatin, Etin. (2012). Strategi Pembelajaran PPKN. Jakarta: Bumi Aksara.

Sudiati, T. (2018). Peningkatan Kinerja Guru dalam Menetapkan Kriteria Ketuntasan Minimal melalui Workshop. Ilmu Pendidikan: Jurnal Kajian Teori dan Praktik Kependidikan, 3(2), 231-237.

Suryana, D. (2013). Pengetahuan tentang strategi pembelajaran, sikap, dan motivasi guru. Jurnal Ilmu Pendidikan, 19(2).

Supardi. (2014). Kinerja Guru. Jakarta: PT Raja Grafindo Persada. 